\title{
Особенности изменения площадей водного зеркала и количества озер степной зоны Восточного Забайкалья
}

\author{
И. Л. Вахнина ${ }^{1,2}$, Е. В. Носкова ${ }^{1}$, М. А. Голятина ${ }^{1}$ \\ ${ }^{1}$ Институт природных ресурсов, экологии и криологии Сибирского отделения \\ Российской академии наук, Российская Федераџия \\ (672014, г. Чита, ул. Недорезова, 16а) \\ ${ }^{2}$ Сибирский федеральный университет, Российская Федерация \\ (660041, г. Красноярск, просп. Свободный, 79)
}

\begin{abstract}
Аннотация: Цель исследования - анализ морфометрических характеристик озер, расположенных в степной зоне Восточного Забайкалья. Meтоды. Определение площади водного зеркала и количества озер выполнено по мультиспектральным снимкам космических аппаратов Landsat TM, ETM+ и OLI с 1989 по 2016 годы с помощью модифицированного нормализованного разностного водного индекса (MNDWI). Оценка погодно-климатических условий и расчет параметров засушливости и увлажнения проведены по данным наблюдений близлежащих метеорологических станций Забайкальского управления по гидрометеорологии и мониторингу окружающей среды. Результаты. Выявлены годы с максимальными и минимальными значениями количества и общей площади водных поверхностей озер. С помощью корреляционного анализа показано, что изменение исследуемых характеристик тесно связано с климатическими условиями территории. Bblвoды. Динамика морфометрических характеристик озер степной зоны Восточного Забайкалья обусловлена влиянием климатических факторов. Последняя сухая фаза климатического цикла совпала с ростом температур теплого периода, что привело к повышенному испарению и к значительному сокращению числа и общей площади водной поверхности озер. Для бессточных озер размеры текущего года являются следствием характера водности ряда предшествующих лет. Снижение размеров может сохраняться и в многоводном году, если этому предшествовал ряд маловодных лет, и увеличение в маловодном, если этот маловодный год наблюдается в пределах многоводного периода.
\end{abstract}

Ключевые слова: степные озера, космоснимки, индекс MNDWI, климат, увлажненность, Забайкалье.

Источник финансирования: Подготовка космических снимков и расчет водного индекса MNDWI проведены в рамках базового проекта IX.137.1.1, климатический анализ выполнен при финансовой поддержке Российского научного фонда (проект № 19-14-00028).

Для цитирования: Вахнина И.Л., Носкова Е.В., Голятина М.А. Особенности изменения площадей водного зеркала и количества озер степной зоны Восточного Забайкалья // Вестник Воронежского государственного университета. Серия География. Геоэкология, 2020, № 3, с. 13-23. DOI: https://doi.org/10.17308/geo.2020.3/3019

\section{ВВЕДЕНИЕ}

По оценкам Межправительственной группы экспертов по изменению климата средняя по земному шару приземная температура воздуха за период с 1906 по 2005 год повысилась на $0,74{ }^{\circ} \mathrm{C}$ [5]. Начиная с 1970-х годов, потепление климата за-

() Вахнина И. Л., Носкова Е.В., Голятина М.А., 2020

В Вахнина Ирина Леонидовна, e-mail: vahnina il@mail.ru метно ускорилось. По данным наблюдений средняя скорость потепления за 1976-2012 годы для земного шара и суши Северного полушария составляет 0,166 и $0,328{ }^{\circ} \mathrm{C} / 10$ лет соответственно, в то время как за период 1901-2012 годы - 0,075 и $0,105{ }^{\circ} \mathrm{C} / 10$ лет [2]. При этом начало XXI века остается самым теплым 12-летием за период инст-

Контент доступен под лицензией Creative Commons Attribution 4.0 License. 


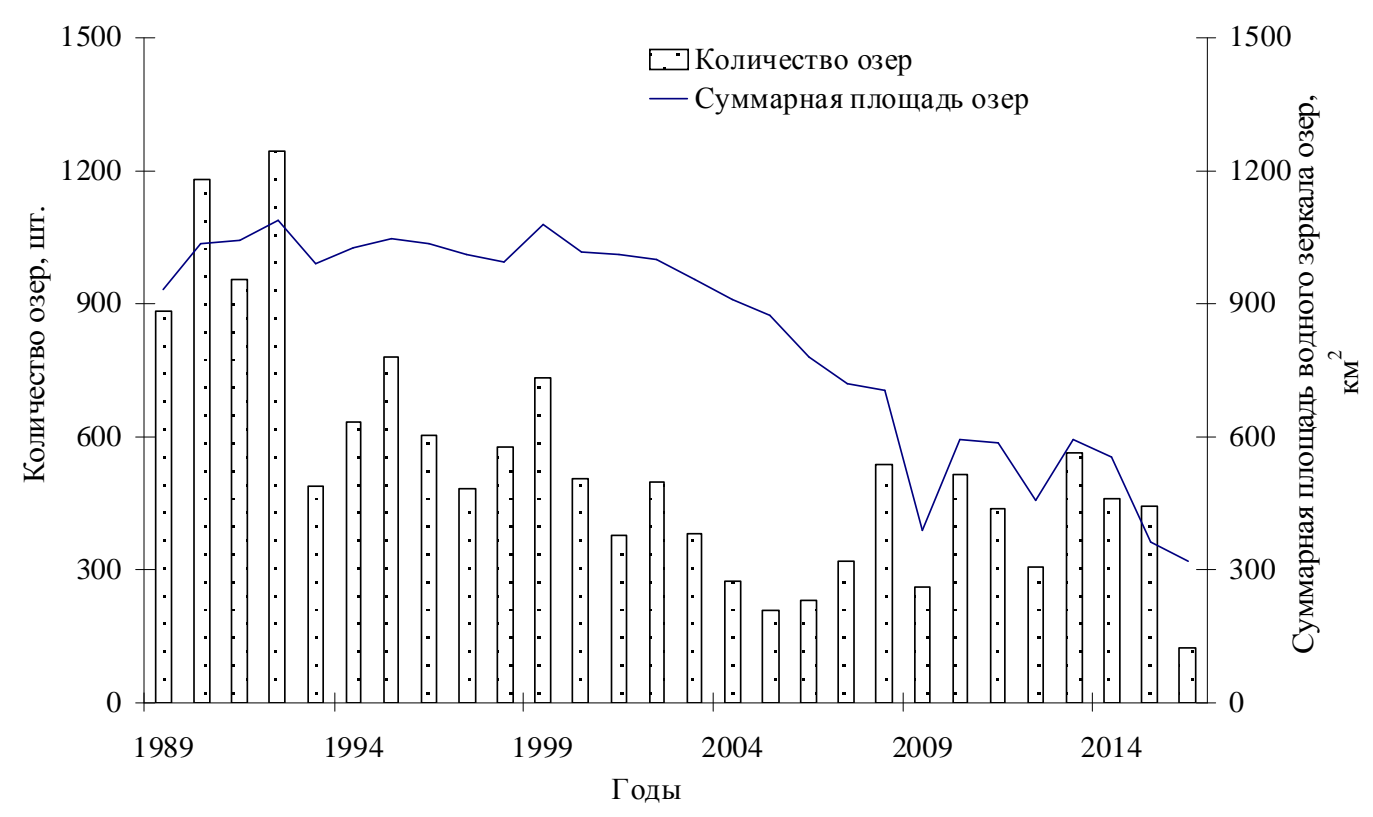

Puc. 1. Изменение количества и суммарной площади бессточных озер исследуемой территории за период с 1989 по 2016 год

[Fig. 1. Change in the number and total area of closed lakes in the study area for the period from 1989 to 2016]

рументальных наблюдений [6]. Данные наблюдений и модельных расчетов показывают, что климат территории России более чувствителен к глобальному потеплению, чем климат многих других регионов земного шара. Температура на территории России растет значительно быстрее глобальной: $0,45^{\circ} \mathrm{C} / 10$ лет, и особенно быстро в полярной области, где скорость роста достигает $0,80^{\circ} \mathrm{C} / 10$ лет [10]. Тренд годовых сумм осадков за период 19762012 годы на большей части территории России положителен. В среднем по России он составляет 0,8 мм/месяц за 10 лет [2].

Рост температуры сопровождается ростом испарения и сокращением стока, что приводит к снижению увлажненности, которое в первую очередь сказывается на экологическом состоянии внутриконтинентальных территорий, в частности, значительным изменениям подвергаются озера. В связи с этим бессточные озера, не имеющие поверхностного стока или подземного отвода в соседние водосборы, водный расход которых осуществляется за счет испарения, являются чувствительными индикаторами, отражающими колебания климата $[4,7,9,11,16,20,21,23,24]$.

Поскольку бессточные озера приурочены в основном к аридным степным и лесостепным зонам их мониторинг позволяет определять особенности функционирования природных и хозяйственных систем региона.

Эффективным и зачастую единственным источником объективной и актуальной информации для анализа динамики изменения водности бессточных озер на обширных и труднодоступных территориях является использование данных дистанционного зондирования Земли. Математические методы обработки многоспектральных изображений поверхности со спутников позволяют получать информацию о пространственно-временных параметрах различных, в том числе водных, объектов [3, 8, 18, 19, 22].

Объекты исследований - озера, расположенные в степной зоне Восточного Забайкалья. Географически территория занимает Онон-Торейскую высокую равнину [17]. Средняя высота рельефа составляет 600-800 метров. Озера преимущественно бессточного типа питания, солоноватые или соленые, неглубокие до 5 метров. В водные климатические периоды их насчитывается до нескольких сотен [3]. Самые большие по площади - ЗунТорей и Барун-Торей. В многоводные периоды их площади достигают соответственно 300 и 580 км² при глубинах до 7 и 5 метров.

На формирование климата в регионе определяющее влияние оказывают восточные муссонные и сухие южные воздушные массы. Окаймляющие Онон-Торейскую равнину хребты защищают ее от проникновения Атлантического и Арктического воздуха. Климат Восточного Забайкалья резкоконтинентальный: среднегодовые температуры воздуха равняются $-0,1--2,0^{\circ} \mathrm{C}$; среднегодовое количество осадков 300-370 мм; короткий безморозный период и высокая продолжительность солнечного сияния. 


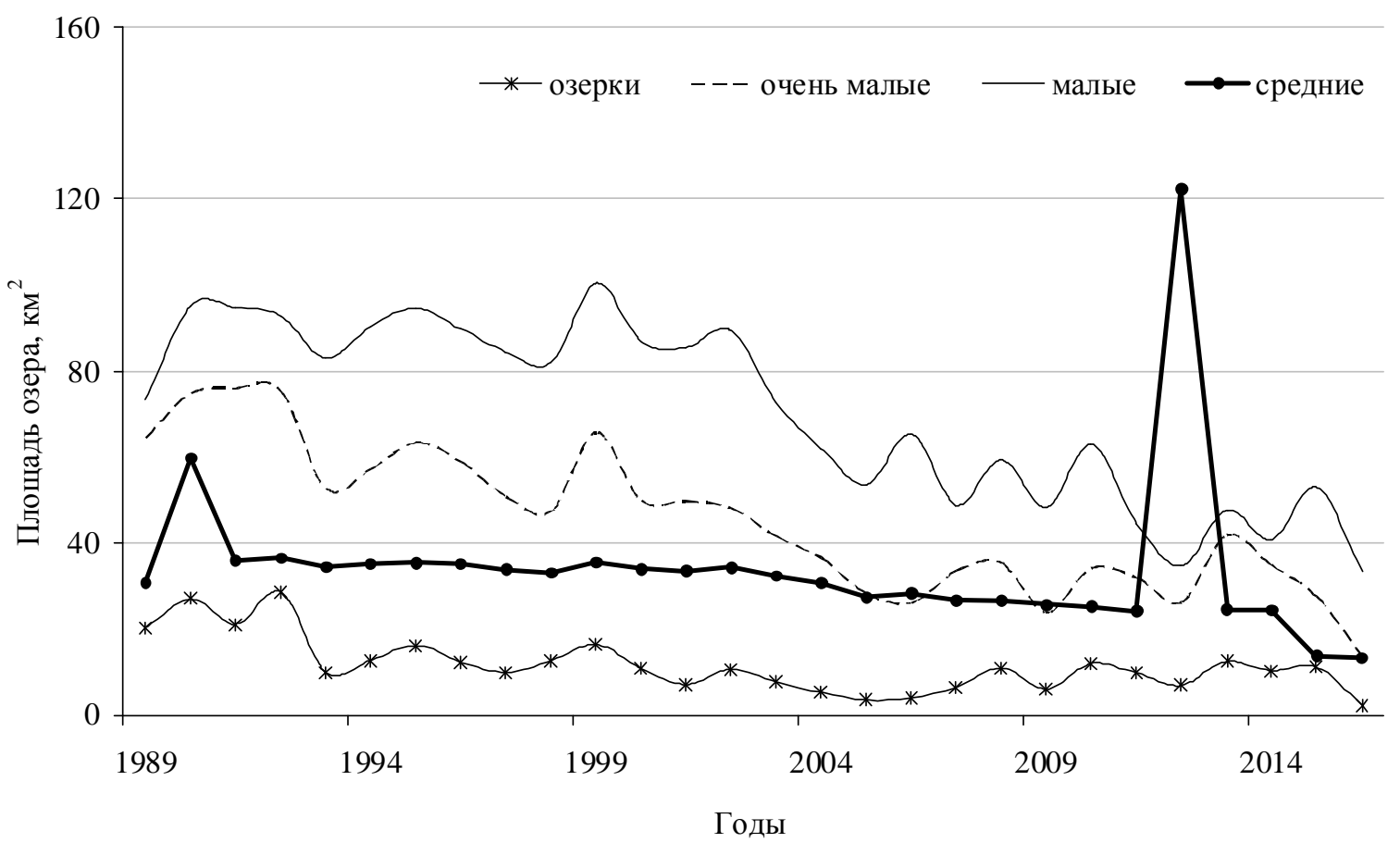

Puc. 2. Изменение площадей водной поверхности бессточных озер исследуемой территории по категориям

[Fig. 2. Change in water surface areas of closed lakes in the study area by categories]

Особенности климата - цикличное чередование влажных и засушливых периодов. Циклы увлажненности определяют динамику изменении площади водных объектов, вплоть до полного исчезновения в засушливые годы. Наибольшей значимостью обладает внутривековой цикл, продолжительностью около 30 лет.

\section{МЕТОДЫ ИССЛЕДОВАНИЯ}

Анализ динамики площадей водного зеркала и количества озер выполнен на площади

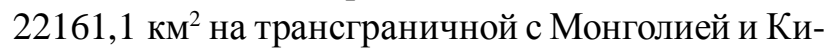
таем территорией, расположенной в пределах степной зоны Восточного Забайкалья.

Для выявления водных поверхностей использовались мультиспектральные снимки космических аппаратов Landsat TM, ETM+ и OLI (http:// earthexplorer.usgs.gov/) [22] за период с 1989 по 2016 год с мая по сентябрь. Эффективность использования космических снимков для исследования водных объектов показана и другими исследователями [15].

Определение площади водного зеркала и количества озер выполнено с помощью модифицированного нормализованного разностного водного индекса (MNDWI) [18, 19], так как ранее было показано, что по сравнению другим спектральным индексом MNDWI обладает большей точностью при дешифрировании водных поверхностей. Ве- личина среднеквадратической ошибки менее 0,08 км [8].

Обработка снимков и расчет водных индексов производились с помощью средств Image Classification и Spatial Analyst ArcGIS 10.

В связи с тем, что многолетние изменения количества озер и площади их водного зеркала преимущественно определяются погодно-климатическими условиями теплого периода года (май-сентябрь), то в работе были проанализированы среднемесячные данные о температуре воздуха и атмосферных осадках за май-сентябрь по данным наблюдений 4 метеорологических станций Забайкальского управления по гидрометеорологии и мониторингу окружающей среды (Акша, Борзя, Нижний Цасучей, Соловьевск) за последние 60 лет (1957-2016 гг.). За этот же промежуток времени рассчитаны гидротермический коэффициент Г. Т. Селянинова (ГТК) и индекс Д. А. Педя (SI).

Климатическая норма рассчитана за 30-летний базовый период (1981-2010 гг.), рекомендованный Всемирной метеорологической организацией [1].

Выявление тенденций климатических изменений проводилось путем расчета и анализа линейных трендов. Тренды во временных рядах вычислялись методом наименьших квадратов. Оценка их статистической значимости выполнялась при помощи критерия Стьюдента при уровне значимости $\alpha=5 \%$. 
Площади и категории исследуемых озер в степной зоне Восточного Забайкалья [Table. Areas and categories of the study lakes in the steppe zone of Eastern Transbaikalia]

\begin{tabular}{|c|c|c|c|c|c|}
\hline № & Oзеро / Lake & $\begin{array}{c}\text { Максимальная } \\
\text { площадь, } \\
\text { км²/год / } \\
\text { Maximum area, } \\
\mathrm{km}^{2} / \text { year } \\
\end{array}$ & $\begin{array}{c}\text { Минимальная } \\
\text { площадь, } \\
\text { км²/год / } \\
\text { Minimum area, } \\
\mathrm{km}^{2} / \text { year } \\
\end{array}$ & $\begin{array}{c}\text { Средняя } \\
\text { площадь, } \\
\text { км² / Average }^{\text {area, } \mathrm{km}^{2}}\end{array}$ & $\begin{array}{c}\text { Категория / } \\
\text { Category }\end{array}$ \\
\hline 1 & $\begin{array}{l}\text { Барун-Торей / Barun- } \\
\text { Torey }\end{array}$ & $\frac{557,8}{1999}$ & $\frac{0,0}{2009}$ & 378,8 & \multirow{2}{*}{$\begin{array}{l}\text { большие / } \\
\text { big }\end{array}$} \\
\hline 2 & Зун-Торей / Zun-Torey & $\frac{301,6}{1999}$ & $\frac{254,7}{2015}$ & 287,9 & \\
\hline 3 & Ножий / Nozhiy & $\underline{20,9}$ & $\frac{9,2}{2016}$ & 15,9 & $\begin{array}{l}\text { средние / } \\
\text { average }\end{array}$ \\
\hline 4 & Кункур / Kunkur & $\frac{9,6}{1999}$ & $\frac{0,8}{2016}$ & 7,2 & \multirow{6}{*}{$\begin{array}{c}\text { малые / } \\
\text { small }\end{array}$} \\
\hline 5 & $\begin{array}{l}\text { Цаган-Нур (Урта- } \\
\text { Харгана) / Tsagan-Nur } \\
\text { (Urta-Khargana) }\end{array}$ & $\frac{7,8}{1999}$ & $\frac{4,2}{2016}$ & 6,2 & \\
\hline 6 & $\begin{array}{l}\text { Цаган-Нур (Нов. } \\
\text { Дурлугуй) / Tsagan- } \\
\text { Nur (Nov. Durluguy) }\end{array}$ & $\frac{6,6}{1999}$ & $\frac{4,4}{2016}$ & 5,5 & \\
\hline 7 & $\begin{array}{l}\text { Apy-Topyм / Aru- } \\
\text { Torum }\end{array}$ & $\frac{4,0}{1999}$ & $\frac{1,6}{2016}$ & 3,1 & \\
\hline 8 & $\begin{array}{l}\text { Баин-Цаган / Bain- } \\
\text { Tsagan }\end{array}$ & $\frac{3,6}{2002}$ & $\frac{2,5}{2016}$ & 3,1 & \\
\hline 9 & $\begin{array}{l}\text { Борзинское / } \\
\text { Borzinskoye }\end{array}$ & $\frac{1,3}{1992}$ & $\frac{0,8}{2005}$ & 1,1 & \\
\hline 10 & $\begin{array}{l}\text { Шихалин-Нур / } \\
\text { Shikhalin-Nur }\end{array}$ & $\frac{2,1}{1989}$ & $\frac{0,2}{2005}$ & 0,9 & \multirow{4}{*}{$\begin{array}{c}\text { очень } \\
\text { малые / very } \\
\text { small }\end{array}$} \\
\hline 11 & $\begin{array}{l}\text { Большая Булугунда / } \\
\text { Bol'shaya Bulugunda }\end{array}$ & $\frac{0,5}{1999}$ & $\frac{0,0}{2016}$ & 0,3 & \\
\hline 12 & Гришкино / Grishkino & $\frac{0,5}{1992}$ & $\frac{0,1}{2009}$ & 0,2 & \\
\hline 13 & Горбунка / Gorbunka & $\frac{0,2}{1999}$ & $\frac{0,0}{2016}$ & 0,1 & \\
\hline 14 & Хилгонта / Khilgonta & $\frac{0,1}{1992}$ & $\frac{0,0}{2016}$ & 0,1 & $\begin{array}{c}\text { озерки / } \\
\text { lakes }\end{array}$ \\
\hline
\end{tabular}

\section{ОБСУЖДЕНИЕ РЕЗУЛЬТАТОВ}

Анализ динамики характеристик озер, выполненный с использованием водного индекса MNDWI, за период с 1989-2016 годы показал, что максимальное количество озер наблюдалось в 1992 году (1245 шт.) с общей площадью водного зеркала 1088 км² (рис. 1). С 1993 года произошло существенное снижение исследуемых показателей, динамика которых выражается достоверным при $5 \%$ уровне значимости отрицательным трендом. Минимальных значений оба показателя достигли в 2016 году. При этом суммарная площадь озер уменьшилась более чем на $70 \%$ по отношению к максимальному количеству и составила 319,4 км², а их количество - в 10 раз.

В зависимости от размеров водной поверхности озер [15] на территории исследования в большем количестве представлены озерки $(0,001$ $\left.0,01 \mathrm{\kappa м}^{2}\right)$, их $67 \%$, и очень малые озера $\left(0,1-1,0\right.$ км² $^{2}$ $-27 \%$. Незначительным, до $5 \%$, числом представлены малые (1,0-10 км²) озера. В категорию средних (10,1-100 км²) и больших (100,1-1000 км²) отнесены по два озера: Хара-Нор и Ножий и БарунТорей и Зун-Торей соответственно.

За сроки наблюдений насчитывалось от 77 (2016 г.) до 965 шт. (1992 г.) озерков. Количество 

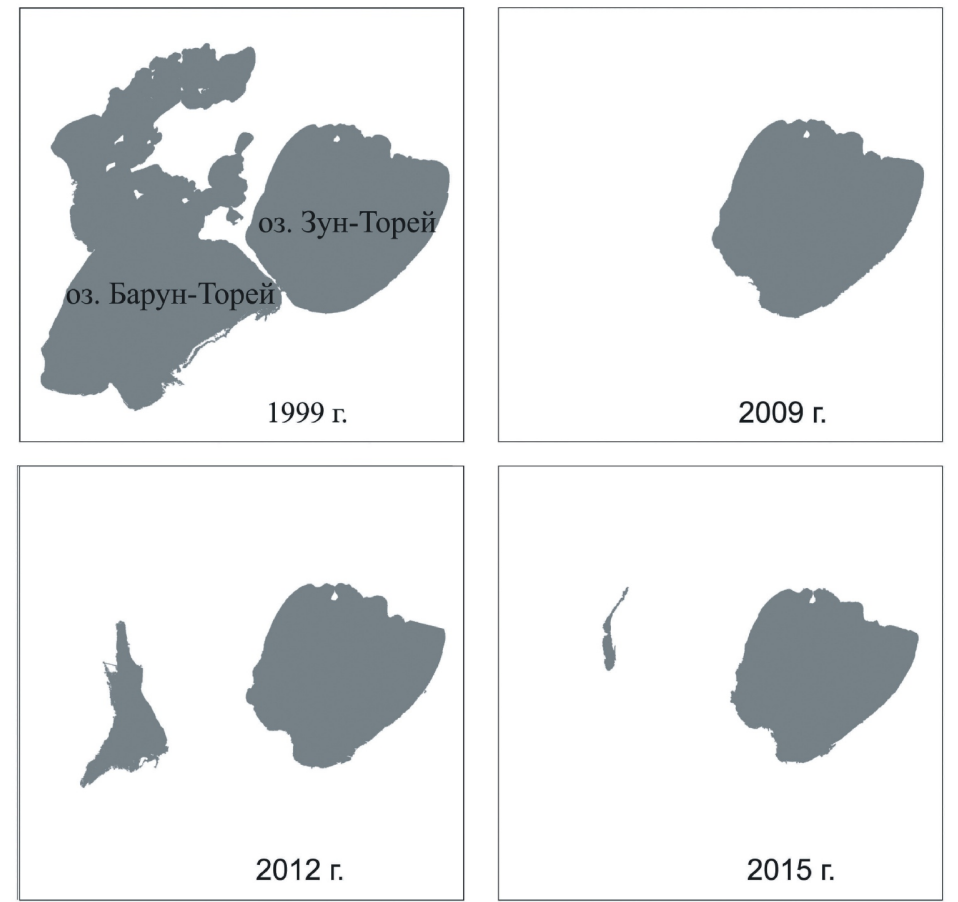
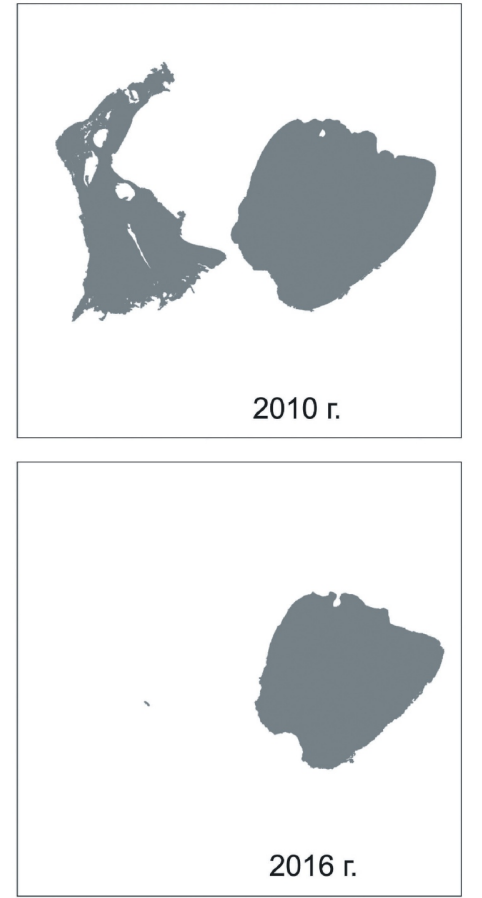

Puc. 3. Изменение площадей водного зеркала оз. Барун-Торей и Зун-Торей (Восточное Забайкалье) по результатам дешифрирования космических снимков Landsat с использованием водного индекса MNDWI [Fig. 3. Change in the area of the water mirror of Lake Barun-Torey and Zun-Torey (East Transbaikalia) according to the results of deciphering satellite images of Landsat using the water index MNDWI]

очень малых озер колебалось от 34 (2016 г.) до 258 шт. (1990 г.). Малые озера варьировали в пределах от 11 (2016 г.) до 38 шт. (1990 г.). К категории средних относилось два озера, но в 2009 и 2012 годах вследствие сокращения площади в эту группу попадало и оз. Барун-Торей.

Анализ изменения количества озер показал, что за период с 1989 по 2016 год их динамика характеризуется отрицательным трендом. Резкое снижение числа озерков произошло в 1993 году, когда их количество с 965 снизилось до 285 шт. С 1992 года шло сокращение количества очень малых озер. Их число только с 2002 года уменьшилось почти вдвое (с 33 до 18).

По суммарной площади водного зеркала озер распределение следующее: большие озера - $80 \%$, малые - $9 \%$, очень малые - $6 \%$, средние $-4 \%$ и озерки занимают $1 \%$ от общей площади озер.

Динамика площадей водного зеркала по категориям озер аналогично количеству характеризуется достоверным отрицательный трендом (рис. 2).

Данный показатель также включает в себя значения, отражающие переход более крупных категорий в более мелкие в маловодные годы. Например, в 2012 году, когда суммарная площадь водной поверхности озер имела тенденцию к снижению, общая площадь средних озер увеличилось в
6 раз, что произошло в связи с усыханием оз. Барун-Торей и переходом его из категории больших озер в средние. Полученная информация свидетельствует о том, что анализ динамики площадей озер по категориям дает некорректные результаты в связи с переходом озер в отдельные годы из одной категории в другую.

В 2013 году озеро Барун-Торей восстановило свою площадь и вновь стало классифицироваться как «большое».

Количество озер является более динамичным показателем по сравнению с изменением площади водного зеркала. В первую очередь пересыхают озера с наименьшей площадью. Их высыхание приводит к сокращению количественного показателя, но в силу их малых размеров, это почти не сказывается на изменении суммарной площади водного зеркала.

Изменение суммарной площади происходит позже. Оно в большей степени связано с усыханием крупных озер.

Для более детального анализа изменения площади водного зеркала на исследуемой территории изучено 14 озер (таблица): Барун-Торей, Зун-Торей, Ножий, Кункур, Хилгонта, Горбунка, Борзинское, Баин-Цаган, Большая Булугунда, Гришкино, Шихалин-Нур, Ару-Торум, Цаган-Нур (Урта-Хар- 


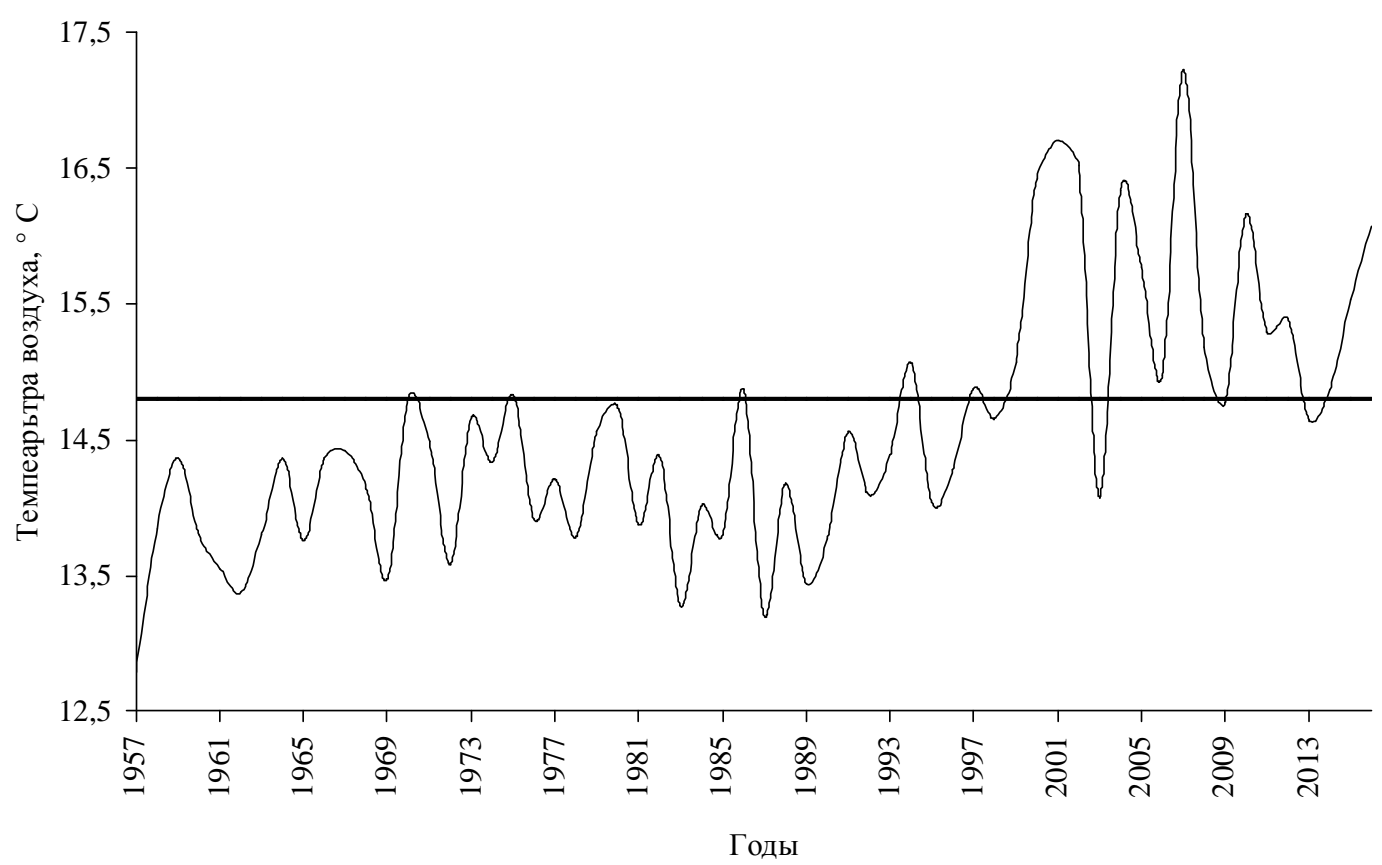

Puc. 4. Многолетние изменения средней температуры воздуха теплого периода (май-сентябрь), осредненной по исследуемым метеостанциям (красной линией показана многолетняя климатическая норма температуры воздуха за теплый период, рассчитанная за 1981-2010 гг.)

[Fig. 4. Long-term changes in the average temperature of the warm period (May-September), averaged over the studied weather stations (the red line shows the long-term climatic norm of the air temperature for the warm period, calculated for 1981-2010)]

гана), Цаган-Нур (Нов. Дурлугуй). Средняя площадь водной поверхности озер по данным ДЗ3 с 1989 по 2016 год составляла от 378,8 (оз. Барун-

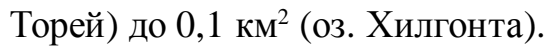

По динамике площадей водного зеркала за исследуемый период выделяется 2 группы озер. Изменение площадей водных поверхностей для исследуемых озер происходит согласованно, о чем свидетельствуют высокие коэффициенты линейной корреляции внутри групп 0,74 и 0,88 . В первую группу вошли все озера из категорий «очень малые» и «озерки» (Гришкино, Хилгонта, Шихалин-Нур, Горбунка, Большая Булугунда), а также озеро Борзинское, которое отнесено к «малым», но его средние размеры лишь на 0,1 км$^{2}$ выше порогового значения для «очень малых» озер. Динамика площадей озер данной группы характеризуется снижением до 2005-2006 годов, а затем незначительным ростом. В 2016 году для всех озер характерно уменьшение площади водного зеркала, а озера Хилгонта, Большая Булугунда и Горбунка полностью пересыхают.

Во вторую группу попали озера, площадь которых превышает 1 км² $^{2}$. Изменение их размеров характеризуется равномерным уменьшением площадей после 1999-2002 годов с минимальными значениями в конце периода наблюдений. Такой вид изменения соответствует озерам Барун-Торей, Зун-Торей, Ножий, Кункур, Баин-Цаган, Ару-Торум, Цаган-Нур (Урта-Харгана), Цаган-Нур (Нов. Дурлугуй).

Из рассматриваемых озер наибольший интерес представляет Барун-Торей, которое является самым крупным и одним из наиболее изученных озер на территории всего Забайкалья. Этот водный объект содового типа тектонического происхождения. В Барун-Торей впадают реки Улдза и Ималка. Озеро соединено протокой с оз. Зун-Торей. Являясь бессточным водоемом, оно служит индикатором в выявлении фаз повышенной и пониженной водности.

Исторические данные и современные сведения подтверждают периодическую наполняемость и пересыхание озера Барун-Торей с разной продолжительностью циклов [10]. Исследования по изменению уровня воды за период с 1965 по 2009 год, выполненное в работе В. А. Обязова [9], показало, что в 1965 году отмечался самый высокий с начала столетия уровень озера. В последующие годы уровень Барун-Торея снижался и достиг минимума в 1982-83 годах, а в 1984 году началось его новое повышение. Максимальный уровень, который 


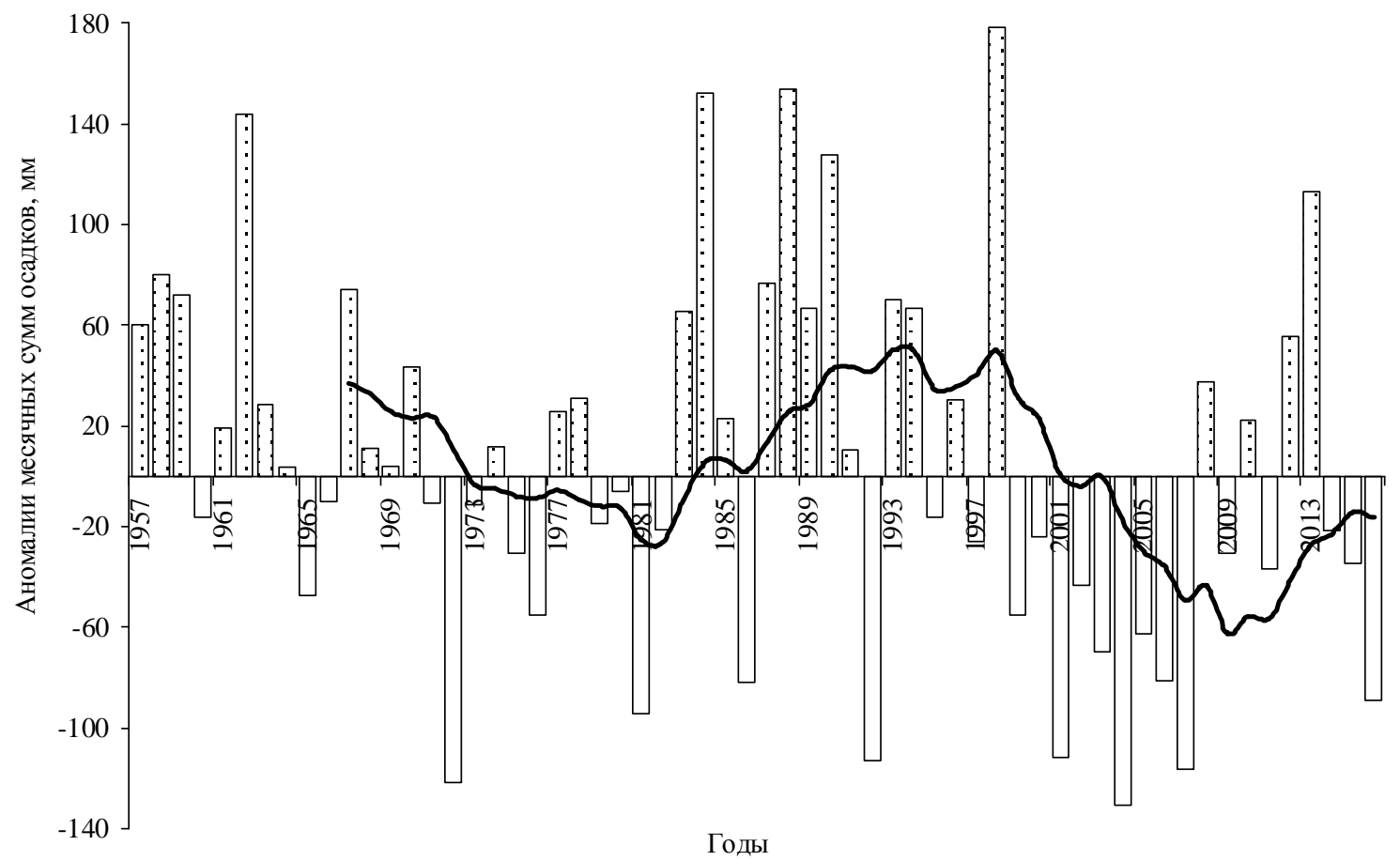

Рuc. 5. Многолетние изменения суммы осадков теплого периода (май-сентябрь), осредненных по исследуемым метеостанциям (красной линией показана сглаженная кривая, полученная 11-летним скользящим осреднением)

[Fig. 5. Long-term changes in the amount of precipitation in the warm period (May-September) averaged over the studied weather stations (the red line shows the smoothed curve obtained by the 11-year moving averaging)]

стал наивысшим уровнем XX века, был отмечен в 1998 году. Последующее снижение уровня завершилось в 2009 году почти полным высыханием озера.

Динамика площади водного зеркала по космоснимкам, выполненная за период с 1989 по 2016 год, согласуется с данными по изменению уровня. Максимальное значение площади - 557,8 км² пришлось на 1999 год (рис. 3). С началом новой аридной фазы размеры озеро Барун-Торей снижались и в 2009 году оно полностью пересохло. В 2010 году площадь озера Барун-Торей восстановилась до 180 км²$^{2}$, что в 2 раза меньше его средней площади за исследуемый период. Следующее снижение площади водного зеркала озера до критических значений наблюдалось в 2015 и 2016 годах

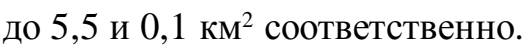

Климатический анализ показал, что за период с 1957 по 2016 год температура воздуха теплого периода (май-сентябрь), осредненная по 4 метеостанциям, расположенным на территории степной зоны Восточного Забайкалья, характеризуется достоверным положительным линейным трендом при 5\%-ном уровне значимости, который составил $0,4{ }^{\circ} \mathrm{C} / 10$ лет. Средние значения температуры колебались в пределах от 13,2 (1987 г.) до $17,2{ }^{\circ} \mathrm{C}$ (2007 г.) (рис. 4). При этом с 1999 года отмечался значительный рост температур, когда на всем протяжении (до 2016 г. включительно) произошло превышение климатической нормы $\left(14,8^{\circ} \mathrm{C}\right)$, pacсчитанной за период 1981-2010 годов. Исключение составлял лишь 2003 год, когда средняя температура воздуха теплого периода равнялась $14,1^{\circ} \mathrm{C}$.

В то же время суммы атмосферных осадков теплого периода с 1999 по 2016 год характеризуются отрицательными аномалиями (рис. 5), рассчитанными как отклонения от среднего за 19812010 гг. В этот период осадки с мая по сентябрь не превышали климатической нормы в 281 мм, а в 2004 и 2007 гг. снижались до 151 и 165 мм соответственно. Исключение составляли 2010, 2008, 2012 и 2013 гг., когда отмечались положительные аномалии.

По разностным интегральным кривым сумм атмосферных осадков четко выделяются 2 полных квазитридцатилетних цикла в режиме увлажненности территории. Но в период 1955-1963 годов происходит выпадение осадков выше нормы, а затем с 1964 по1982 год следует сухая фаза. С 1983 года вновь наступает влажный период, продолжающийся до 1998 года, а с 1999 года начинается новая сухая фаза. По нашим данным начало влажного периода нового климатического цикла в Восточном Забайкалье наступило в 2011 году. 
Однако внутри каждого цикла отмечаются аномалии. Например, в 1992 году в период влажного цикла количество осадков снизилось до 168 мм, что привело к значительному усыханию озер.

С помощью корреляционного анализа установлена положительная достоверная при уровне значимости $\alpha=5 \%$ связь между количеством озер на исследуемой территории с атмосферными осадками $(r=0,37)$ и гидротермическим коэффициентом Г. Т. Селянинова $(r=0,43)$ и отрицательная с температурами $(r=-0,60)$ и индексом засушливости Д. А. Педя $(r=-0,58)$. Кросскорреляционным анализом выявлено, что значимые связи с исследуемыми климатическими характеристиками отмечаются не только для текущего года, но и для 15 предшествующих лет. Связь между общей площадью водного зеркала озер и метеопараметрами отмечается только через 4-6 лет, что также подтверждается достоверными значениями корреляции.

\section{ЗАКЛЮЧЕНИЕ}

Динамика количества бессточных озер и общей площади их водного зеркала в степной зоне Восточного Забайкалья, выявленная с применением модифицированного нормализованного разностного водного индекса MNDWI, обусловлена влиянием климатических факторов. Последняя сухая фаза климатического цикла совпала с ростом температур теплого периода, что привело к повышенному испарению и к значительному сокращению числа озер и их общей площади.

Количество озер является более динамичным показателем, чем их площадь. В первую очередь пересыхают озера с наименьшей площадью - озерки и очень малые озера. Учитывая, что они составляют $97 \%$ от общего числа, их высыхание приводит к сокращению количественного показателя. Однако в силу малых размеров это практически не сказывается на изменении суммарной площади водного зеркала озер на исследуемой территории. Изменение суммарной площади происходит позже: оно в большей степени связано с усыханием крупных озер. Для бессточных озер размеры текущего года являются следствием характера водности ряда предшествующих лет. Снижение размеров может иметь место и в многоводном году, если этому предшествовал ряд маловодных лет, и увеличение в маловодном, если этот маловодный год наблюдается в пределах многоводного периода.

В связи с окончанием в 2011 году сухой фазы в климатическом цикле и запаздыванием в реакции озер на увлажненность территории в ближайшие годы следует ожидать восстановления уровня озер в степной зоне Восточного Забайкалья.

\section{СПИСОК ЛИТЕРАТУРЫ}

1. ВМО-№ 1203. Руководящ⿻ие указания ВМО по расчету климатических норм, 2017.

2. Второй оченочный доклад Росгидромета об изменениях климата и их последствиях на территории Российской Федерации / Общее резюме. М., ГУ «НИЦ Планета», 2014. 61 с.

3. Голятина М.А., Курганович К.А. Оценка изменения площадей водной поверхности Ивано-Арахлейских озер Забайкалья по данным дистанционного зондирования // Вестник Забайкальского государственного университета, 2017, т. 23, № 6, с. 4-11.

4. Давыдова Н. Д. Динамика показателей степных геосистем Юго-Восточного Забайкалья в условиях глобальных изменений климата // Международный журнал прикладных и фундаментальных исследований, 2014, № 4, c. 120-125.

5. Изменение климата. Обобщающий доклад. Вклад рабочих групп I, II и III в Четвертый доклад об оценке Межправительственной группы экспертов по изменению климата. Женева, Швейцария, МГЭИК, 2008. $104 \mathrm{c}$.

6. Изменение климата. Обобщающий доклад. Вклад Рабочих групп I, II и III в Пятый оченочный доклад Межправительственной группь экспертов по изменению климата. МГЭИК: Женева, Швейцария, 2014. $163 \mathrm{c}$.

7. Клиге Р.К., Евсеева Л.С. Аномалии режима вод суши // Современные глобальные изменения природной средbl, 2006, т. 1, с. 246-269.

8. Курганович К. А., Носкова Е. В. Использование водных индексов для оценки изменения площадей водного зеркала степных содовых озер юго-востока Забайкалья по данным дистанционного зондирования // Вестник Забайкальского государственного университета, 2015, № 6 (121), с. 16-24.

9. Обязов В. А. Изменения климата и гидрологический режим рек и озер в Даурском экорегионе / Проблемы адаптации к изменению климата в бассейнах рек Даурии: экологические и водохозяйственные аспекты. // Чита: Экспресс-издательство, 2012, с. 24-45.

10. Обязов В.А. Связь колебаний водности озер степной зоны Забайкалья с многолетними гидрометеорологическими изменениями на примере Торейских озер // Известия РГО, 1994, вып. 5, с. 48-54.

11. Севастьянов Д. В. Колебания увлажненности и развитие лимносистем в Гобийской долине озер (Монголия) // Аридные экосистемы, 2000, т. 6, №11-12, c. $77-88$.

12. Седьмое национальное сообщение Российской Федерации, представленное в соответствии со статьями 4 и 12 Рамочной Конвенции Организации Объединенных Наџий об изменении климата и статьей 7 Киотского протокола. М., 2017. 348 с. 
13. Скляров Е. В., Склярова О. А., Меньшагин Ю. В., Данилова М.А. Минерализованные озера Забайкалья и Северо-Восточной Монголии: особенности распространения и рудогенерирующий потенциал // География и природные ресурсы, 2011, № 4, с. 29-39.

14. Теоретические вопросы классификации озер / Под ред. Н. П. Смирнова. СПб., 1993, с. 122-186.

15. Шевырев С. Л., Анциферова Г.А., Русова Н.И., Хамзикеева М.Ж. Анализ космических снимков как метод контроля природных и антропогенных процессов на примере среднего течения Вороны (Тамбовская область) // Вестник Воронежского государственного университета. Серия: География. Геоэкология, 2013, № 1, c. 35-39.

16. Якутин М.В., Анопченко Л. Ю., Пучнин А.Н. Особенности экологического мониторинга озер Сибири в условиях глобального изменения климата // Интерэкспо Гео-Сибирь, 2018, т. 4, № 2, с. 133-144.

17. Bazhenova O.I., Kobylkin D. V., Makarov S. A. Reconstructing the Aeolian Processes in Daurian Steppes During Arid Phases of Morphogenesis // Geography and Natural Resources, 2015, vol. 36, issue 3, pp. 289-299.

18. Gao B.C. NDWI - A normalized difference water index for remote sensing of vegetation liquid water from space // Remote Sens. Environ, 1996, 58, pp. 257-266.

19. Feyisa G.L., Meilby H., Fensholt R., Proud S.R. Automated water extraction index: A new technique for surface water mapping using Landsat imagery // Remote Sens. Environ, 2014, no. 140, pp. 23-35.

20. Im S.T., Kharuk V.I., Rakityanskaya N.M., Golyukov A.S. Climate-induced lake dynamics in the Transbaikalia forest-steppe ecotone // Contemporary Problems of Ecology, 2015, vol. 8, no. 6, pp. 680-686.

21. Kuklin A.P., Tsybekmitova G. Ts., Gorlacheva E.P. State of lake ecosystems in Onon-Torei plain in 1983-2011 (Eastern Transbaikalia) // Arid Ecosystems, 2013, vol. 3 (3), pp. 122-130. DOI: 10.1134/s2079096113030062.

22. Rokni K., Ahmad A., Selamat A., Hazini S. Water Feature Extraction and Change Detection Using Multitemporal Landsat Imagery // Remote Sens. Environ, 2014, no. 6, pp. 4173-4189.

23. Zamana L. V., Borzenko S. V. Hydrogeochemical regime of saline lakes in the Southeastern Transbaikalia // Geography and Natural Resources. 2010, vol. 31 (4), pp. 370-376. DOI: 10.1016/j.gnr.2010.11.011.

24. Zamana L. V., Vakhnina I. L. Hydrochemistry of salt lakes in Southeastern Transbaikalia (Russia) in the time of arid phase of climate change at the beginning of the XXI century // Acta Geologica Sinica, 2014, vol. 88, supp. 1, pp. 36-38. DOI: 10.1111/1755-6724.12265_15.

Конфликт интересов: Авторы декларируют отсутствие явных и потенциальных конфликтов интересов, связанных с публикацией настоящей статьи.

Поступила в редакциню: 08.10.2019 Принята к публикаичи 26.07.2020

\title{
GEOGRAPHY
}

UDC 528.88, 556.15

DOI: https://doi.org/10.17308/geo.2020.3/3019

ISSN 1609-0683

\section{Features of Changein Area of a Water Mirror and the Number of Lakes in the Steppe Zone of the Eastern Transbaikalia}

\author{
I. L. Vakhnina ${ }^{1,2} \bowtie$, E. V. Noskova ${ }^{1}$, M. A. Golyatina ${ }^{1}$ \\ ${ }^{1}$ Institute of Natural Resources, Ecology and Cryology of the Siberian Branch RAS, Russian Federation \\ (16a, Nedorezova st., Chita, 672014) \\ ${ }^{2}$ Siberian Federal University, Russian Federation \\ (79, Svobodny Ave., Krasnoyarsk, 660041) \\ Abstract: The aim of the study is to analyze the morphometric characteristics of lakes located in the \\ steppe zone of the Eastern Transbaikalia. Methods. The area of the water surface and the number of lakes were \\ determined using multispectral images of the Landsat TM, ETM + and OLI spacecraft from 1989 to 2016 \\ using modified normalized difference water index (MNDWI). The assessment of weather and climatic condi- \\ tions and the calculation of the parameters of aridity and humidification were carried out according to the
}

(C) Vakhnina I.L., Noskova E. V., Golyatina M.A., 2020

\Irina L. Vahnina, e-mail: vahnina il@mail.ru

cc) (i) The content is available under Creative Commons Attribution 4.0 License. 
observations of nearby meteorological stations of the Trans-Baikal Department for Hydrometeorology and Environmental Monitoring. Results. Years with maximum and minimum values of the number and total area of lake water surfaces have been identified. Correlation analysis showed that changes in the studied characteristics are closely related to the climatic conditions of the territory. Conclusions. The dynamics of the morphometric characteristics of the lakes in the steppe zone of the Eastern Transbaikalia is due to the influence of climatic factors. The last dry phase of the climate cycle coincided with an increase in temperatures during the warm period, which led to increased evaporation and a significant reduction in the number and total area of the water surface of lakes. For closed lakes, the size of the current year is a consequence of the nature of the water content of a number of previous years. A decrease in size can also take place in a high-water year, if this was preceded by a number of low-water years, and an increase in a low-water year, if this low-water year is observed within a high-water period.

Key words: steppe lakes, satellite images, MNDWI index, climate, humidity, Transbaikalia.

Funding: Preparation of satellite images and calculation of the MNDWI water index were carried out within the framework of the basic project IX.137.1.1, climate analysis was carried out with the financial support of the Russian Science Foundation (project No. 19-14-00028).

For citation: Vakhnina I. L., Noskova E. V., Golyatina M. A. Features of change in area of a water mirror and the number of lakes in the steppe zone of the Eastern Transbaikalia. Vestnik Voronezskogo gosudarstvennogo universiteta. Geografia geoekologia, 2020, No. 3, pp. 13-23. (In Russ.) DOI: https://doi.org/10.17308/geo.2020.3/3019

\section{REFERENCES}

1. VMO-№ 1203. Rukovodyashchiye ukazaniya VMO po raschetu klimaticheskikh norm [WMO Guidelines for the calculation of climate standards]. 2017. (In Russ.)

2. Vtoroy otsenochnyy doklad Rosgidrometa ob izmeneniyakh klimata i ikh posledstviyakh na territorii Rossiyskoy Federatsii. Obshcheye rezyume [The second assessment report of Roshydromet on climate change and its consequences in the Russian Federation / General summary]. Moscow, Publ. GU "NITS Planeta", 2014. 61 p. (In Russ.)

3. Golyatina M.A., Kurganovich K.A. Otsenka izmeneniya ploshchadey vodnoy poverkhnosti Ivano-Arakhleyskikh ozer Zabaykal'ya po dannym distantsionnogo zondirovaniya [Assessment of changes in the water surface area of Ivano-Arakhleya Lakes of Transbaikalia according to remote sensing data]. Vestnik Zabaykal'skogo gosudarstvennogo universiteta, 2017, v. 23, no. 6, pp. 4-11. (In Russ.)

4. Davydova N. D. Dinamika pokazateley stepnykh geosistem Yugo-Vostochnogo Zabaykal'ya v usloviyakh global'nykh izmeneniy klimata [Dynamics of indicators of steppe geosystems of the South-East Transbaikalia under the conditions of global climate changes]. Mezhdunarodnyy zhurnal prikladnykh i fundamental'nykh issledovaniy, 2014, no. 4, pp. 120-125. (In Russ.)

5. Izmeneniye klimata. Obobshchayushchiy doklad. Vklad rabochikh grupp I, II $i$ III $v$ Chetvertyy doklad ob otsenke Mezhpravitel'stvennoy gruppy ekspertov po izmeneniyu klimata [Changing of the climate. Summary report. Contribution of Working Groups I, II and III to the Fourth Assessment Report of the Intergovernmental Panel on Climate Change]. MGEIK: Zheneva, Shveytsariya, 2008. 104 p. (In Russ.)

6. Izmeneniye klimata. Obobshchayushchiy doklad. Vklad Rabochikh grupp I, II i III v Pyatyy otsenochnyy doklad Mezhpravitel'stvennoy gruppy ekspertov po izmeneniyu klimata [Climate Change: Synthesis Report.
Contribution of Working Groups I, II and III to the Fifth Assessment Report of the Intergovernmental Panel on Climate Change]. MGEIK: Zheneva, Shveytsariya, 2014. 163 p. (In Russ.)

7. Klige R. K., Yevseyeva L. S. Anomalii rezhima vod sushi [Anomalies of the land water regime]. Sovremennyye global'nyye izmeneniya prirodnoy sredy, 2006, v. 1, pp. 246269. (In Russ.)

8. Kurganovich K.A., Noskova E. V. Ispol'zovaniye vodnykh indeksov dlya otsenki izmeneniya ploshchadey vodnogo zerkala stepnykh sodovykh ozer yugo-vostoka Zabaykal'ya po dannym distantsionnogo zondirovaniya [The use of water indices to assess changes in the water surface of steppe soda lakes in the southeast of Transbaikalia, according to remote sensing data]. Vestnik Zabaykal'skogo gosudarstvennogo universiteta, 2015, no. 6 (121), pp. 1624. (In Russ.)

9. Obyazov V. A. [Climate change and the hydrological regime of rivers and lakes in the Daurian ecoregion]. Problemy adaptatsii k izmeneniyu klimata $v$ basseynakh rek Daurii: ekologicheskiye i vodokhozyaystvennyye aspekty. Chita, Ekspress-Publ., 2012, pp. 24-45. (In Russ.)

10. Obyazov V. A. Svyaz' kolebaniy vodnosti ozer stepnoy zony Zabaykal'ya s mnogoletnimi gidrometeorologicheskimi izmeneniyami na primere Toreyskikh ozer [The relationship of water fluctuations in the lakes of the steppe zone of Transbaikalia with long-term hydrometeorological changes on the example of the Torean lakes]. Izvestiya $R G O$, 1994, v. 5, pp. 48-54. (In Russ.)

11. Sevast'yanov D. V. Kolebaniya uvlazhnennosti i razvitiye limnosistem v Gobiyskoy doline ozer (Mongoliya) [Humidity fluctuations and the development of limnosystems in the Gobi lakes valley (Mongolia)]. Aridnyye ekosistemy, 2000, v. 6, no. 11-12, pp. 77-88. (In Russ.)

12. Sed'moye natsional'noye soobshcheniye Rossiyskoy Federatsii, predstavlennoye v sootvetstvii so stat'yami $4 i$ 12 Ramochnoy Konventsii Organizatsii Ob"yedinennykh 
Natsiy ob izmenenii klimata i stat'yey 7 Kiotskogo protokola [The Seventh National Communication of the Russian Federation submitted in accordance with Articles 4 and 12 of the United Nations Framework Convention on Climate Change and Article 7 of the Kyoto Protocol]. Moscow, 2017, 348 p. (In Russ.)

13. Sklyarov Y. V., Sklyarova O. A., Men'shagin Y. V., Danilova M.A. Mineralizovannyye ozera Zabaykal'ya i Severo-Vostochnoy Mongolii: osobennosti rasprostraneniya i rudogeneriruyushchiy potentsial [Mineralized lakes of Transbaikalia and Northeast Mongolia: distribution features and ore-generating potential]. Geografiya i prirodnyye resursy, 2011, no. 4, pp. 29-39.

14. Teoreticheskiye voprosy klassifikatsii ozer [Theoretical questions of the classification of lakes]. Pod red. N.P. Smirnova. St. Petersburg, 1993, pp. 122-186. (In Russ.)

15. Shevyrev S.L., Antsiferova G.A., Rusova N.I., Khamzikeeva M.Zh. Analiz kosmicheskikh snimkov kak metod kontrolya prirodnykh i antropogennykh protsessov na primere srednego techeniya Vorony (Tambovskaya oblast') [Analysis of satellite images as a method of control of natural and anthropogenic processes (the middle flow of the Vorona river is an example)]. Vestnik Voronezskogo gosudarstvennogo universiteta. Geografia geoekologia, 2013, no. 1, pp. 35-39. (In Russ.)

16. Yakutin M. V., Anopchenko L. Y., Puchnin A. N. Osobennosti ekologicheskogo monitoringa ozer Cibiri v usloviyakh global'nogo izmeneniya klimata [Features of ecological monitoring of Siberian lakes in the context of global climate change]. Interekspo Geo-Sibir', 2018, v. 4. no. 2, pp. 133-144. (In Russ.)

17. Bazhenova O.I., Kobylkin D. V., Makarov S. A. Reconstructing the Aeolian Processes in Daurian Steppes During Arid Phases of Morphogenesis. Geography and

Вахнина Ирина Леонидовна

кандидат биологических наук, заведующий лабораторией географии и регионального природопользования Института природных ресурсов, экологии и криологии Сибирского отделения Российской академии наук, г. Чита; сотрудник Сибирского федерального университета, г. Красноярск, Российская Федерация, ORCID: https://orcid.org/0000-0001-5111-6255, e-mail: vahnina il@mail.ru

Носкова Елена Викторовна

кандидат географических наук, младший научный сотрудник лаборатории географии и регионального природопользования Института природных ресурсов, экологии и криологии Сибирского отделения Российской академии наук, г. Чита, Российская Федерация, ORCID: https://orcid.org/0000-0001-9782-1996, e-mail: elenanoskova-2011@mail.ru

Голятина Марина Алексеевна

аспирант Института природных ресурсов, экологии и криологии Сибирского отделения Российской академии наук; г. Чита, Российская Федерация, e-mail: marinasosnina1993@yandex.ru
Natural Resources, 2015, vol. 36, issue 3, pp. 289-299.

18. Gao B.C. NDWI - A normalized difference water index for remote sensing of vegetation liquid water from space. Remote Sens. Environ, 1996, 58, pp. 257-266.

19. Feyisa G.L., Meilby H., Fensholt R., Proud S. R. Automated water extraction index: A new technique for surface water mapping using Landsat imagery. Remote Sens. Environ, 2014, no. 140, pp. 140. 23-35.

20. Im S. T., Kharuk V. I., Rakityanskaya N. M., Golyukov A. S. Climate-induced lake dynamics in the Transbaikalia forest-steppe ecotone. Contemporary Problems of Ecology, 2015, vol. 8, no. 6, pp. 680-686.

21. Kuklin A.P., Tsybekmitova G. Ts., Gorlacheva E.P. State of lake ecosystems in Onon-Torei plain in 1983-2011 (Eastern Transbaikalia). Arid Ecosystems, 2013, vol. 3 (3), pp. 122-130. DOI: 10.1134/s2079096113030062.

22. Rokni K., Ahmad A., Selamat A., Hazini S. Water Feature Extraction and Change Detection Using Multitemporal Landsat Imagery. Remote Sens. Environ, 2014, no. 6, pp. 4173-4189.

23. Zamana L. V., Borzenko S. V. Hydrogeochemical regime of saline lakes in the Southeastern Transbaikalia. Geography and Natural Resources, 2010, vol. 31 (4), pp. 370-376. DOI: 10.1016/j.gnr.2010.11.011.

24. Zamana L. V., Vakhnina I.L. Hydrochemistry of salt lakes in Southeastern Transbaikalia (Russia) in the time of arid phase of climate change at the beginning of the XXI century. Acta Geologica Sinica, 2014, vol. 88, supp. 1, pp. 36-38. DOI: 10.1111/1755-6724.12265_15.

Conflict of interests: The authors declare no information of obvious and potential conflicts of interest related to the publication of this article.

Received: 08.10.2019

Accepted: 26.07.2020

Irina L. Vahnina

Cand. (Biol.) Sci., Head of Laboratory of Geography and Regional Nature Management, Institute of Natural Resources, Ecology and Cryology of the Siberian Branch of the RAS, Chita, employee of the Siberian Federal University, Krasnoyarsk, Russian Federation, ORCID: https://orcid.org/0000-0001-5111-6255, e-mail: vahnina_il@mail.ru

\section{Elena V. Noskova}

Cand. (Geogr.) Sci., Junior Researcher of Laboratory of Geography and Regional Nature Management, Institute of Natural Resources, Ecology and Cryology of the Siberian Branch of the RAS, Chita, Russian Federation, ORCID: https://orcid.org/0000-0001-9782-1996, e-mail:

elena-noskova-2011@mail.ru

Marina A. Golyatina

Post-graduate student of the Institute of Natural Resources, Ecology and Cryology of the Siberian Branch of the RAS, Chita, Russian Federation, e-mail:

marina-sosnina1993@yandex.ru 